ESJ Social Sciences

\title{
Accrual Accounting Practice and Financial Performance in Local Governments of Cameroon
}

\author{
Awasom Susana Yene Chimy \\ Department of Management, University of Buea, \\ South West Region, Cameroon \\ Fossung Micheal Forzeh \\ Vice Dean, Faculty of Social and Management Sciences, \\ University of Buea, South West Region, Cameroon
}

Doi:10.19044/esj.2021.v17n23p269

Submitted: 14 June 2021

Accepted: 14 July 2021

Published: 31 July 2021
Copyright 2021 Author(s)

Under Creative Commons BY-NC-ND

4.0 OPEN ACCESS

Cite As:

Yene Chimy A.S. \& Forzeh F.M. (2021). Accrual Accounting Practice and Financial Performance in Local Governments of Cameroon. European Scientific Journal, ESJ, 17(23), 269. https://doi.org/10.19044/esj.2021.v17n23p269

\section{Abstract}

This paper focuses on assessing the relationship between accrual accounting practice and financial performance in local governments in Cameroon. Using accountability and efficiency as performance proxies, the study employs a mix of qualitative and quantitative research approaches with a triangulate method of data collection. In a population of 374 councils, 50 councils were sampled and clustered according to their statutory council categories. Both descriptive and inferential statistics were used with a multiple regression analysis on panel data to test the relationship between accrual accounting practice and financial performance within council categories. The findings revealed that about $77 \%$ of councils (predominantly rural councils) practicing mild accrual accounting scored a higher financial performance. Meanwhile, $23 \%$ of councils (mostly city councils) practicing a moderate and sometimes strong accrual accounting had a lower financial performance. The pooled regression analysis showed a $13 \%$ insignificant but positive correlation between financial performance and accrual accounting practice. These findings where then backed up with inferences drawn from interviews, discussions as well as content study of accounting books. It revealed that councils have the latitude to navigate from mild, moderate, and strong accrual accounting practice as the need arose. Accrual accounting practice should be 
sequenced in ways that councils can focus on mild accrual accounting practice, and it should move to a higher level of moderate and full accrual accounting only when they can afford the expertise and infrastructural resources needed to yield a significant performance result.

Keywords: New Public Management (NPM), Accrual accounting, accountability, efficient financial performance

\section{Introduction}

The importance of decentralizing governance and public service delivery to local community has become a focus in public sector financial management, accountability, and performance discourses in recent times. Local governments, as decentralised entities in Cameroon, were spelt out in the first democratic constitution of 1996 as artificial persons endowed with administrative and financial autonomy to manage the economic, social, hygiene, sports, and cultural activities of municipalities in Cameroon (Akouafane, 2009; Banilon et al., 2012).

Many reasons can be advanced for decentralizing governance and the management of state resources towards the people. A host of Cameroonian scholars like Bekolo (2020), Chia (2018), Tani (2012), and Kofele-Kale (2011) opined that there was general disillusionment with the political regime and its bad system of governance manifested through corruption, nepotism, social injustice, poor public service delivery, and inadequate accountability mechanism that was deemed irksome and suffocating. Problems of accountability and transparency, characteristic of the ultra-centralized Jacobin administrative systems, were inherent in the unitary and republican state of Cameroon.

This consequently galvanized internal pressures from ethnic and regional groups yearning for a greater control and participation in local governance processes that was in the hands of a few privileged elites of the ruling class. Such steam for a more democratic and accountable governance triggered a series of reform agenda championed by external pressures from the $\mathrm{IMF} /$ Bretton Wood measures to transform such bureaucratic government to be more citizen-oriented (Shamsul, 2007; Kilelo, 2015). It became mandatory to the traditional hyper-centralized Government of Cameroon as one of the recipients of World Bank neoliberal policies to redefine its decentralization machinery through a series of statutory provisions to speed up reforms in the local government. Amidst a culmination of these donor-driven reforms in guise of New Public Management, measures were taken to speed up the administrative, fiscal, and financial decentralisation processes (TSOWA, 2017; Banlilon, 2012). Among them was the introduction of private-style 
financial management and accounting techniques for an accountable and efficient management of financial resources in councils of Cameroon.

Accrual accounting was then introduced in councils in Cameroon in 1998 and modified in 2010 by a decree on a new harmonised Budgetary Nomenclature and Accounting Plan on accrual basis promulgated to accommodate the new resources transferred to councils by the line of ministerial departments. Other structural changes such as the introduction of organisational charts with specific job profiles became eminent with the quest for more professional competences to meet the exigencies of this new financial and accounting technology. The government, in partnership with resident international bodies particularly the Deutsche Gesellschaft für Internationale Zusammenarbeit (GIZ), organised a series of informative and formative seminars for council financial and accounting officials. With the adoption and implementation of all the NPM financial reform laws, are councils more accountable and efficient as envisaged?

\section{The Problem Statement}

Following the audit bench report of the supreme court of Cameroon, not up to 25 percent of councils are able to produce financial reports on accrual basis since its official implementation in 2006. In fact the production rate of the management account of councils between 2014 and 2016 declined from $23.52 \%$ to $10.96 \%$. Municipal authorities were consequently often convicted for financial malpractices, irregularities, and discrepancies in figures observed in the presentation of the few financial statements that were supposed to be produced on accrual basis (Audit Bench of Cameroon, 2016). When policy and decision making in councils is based on such poor quality in financial reporting, the state of financial performance becomes doubtful. This is evidenced by the fact that after over two decades of financial reforms, local governments in Cameroon are still entangled with the problem of managing human, material, and financial resources (Bekolo, 2020; Cheka, 2007). Despite the statutory transfer of financial resources and competences to municipalities, there was a general cry by citizenry that such resources hardly trickled down to their benefit (Banlilon, 2012). With these backdrops, one may interrogate why there is low output and poor financial reporting outcomes of accrual accounting in councils in Cameroon.

Accounting professionals have acknowledged that there are basically two basis of accounting, the cash base and accrual-based system (IPSAS, 2014; Deloitte, 2020). Others like GASB (2006) and Chan (2008) displayed a broader spectrum of the application of these accounting basis that range from cash and modified cash based to mild, modified, and full accrual basis of accounting for financial reporting. While an entity may use any of the accounting basis as entry point for its transaction analysis and accounting, the 
accounting basis practiced in the entire government beginning with the local government sector in Cameroon seem to be a combination that has not yet been adequately captured by accounting researchers as there is little or no empirical consensus on this.

In PwC (2015) world survey, for instance, modified accrual was found to be the basis of accounting practiced in the government of Cameroon. Meanwhile in IFAC reported by Cavanagh et al. (2016) on mapping the spread of accrual accounting in the public sector in the world, the government of Cameroon was presented as one of the $57 \%$ of those still operating under pure cash-based system. In same vain, IFAC et al. (2018) world financial accountability index report on accrual basis has no data for the Government of Cameroon, while OECD \& IMF data from public opinion holds that the Cameroon public sector is on cash basis as illustrated in the map reported by Canavagh et al. (2016) as shown below.

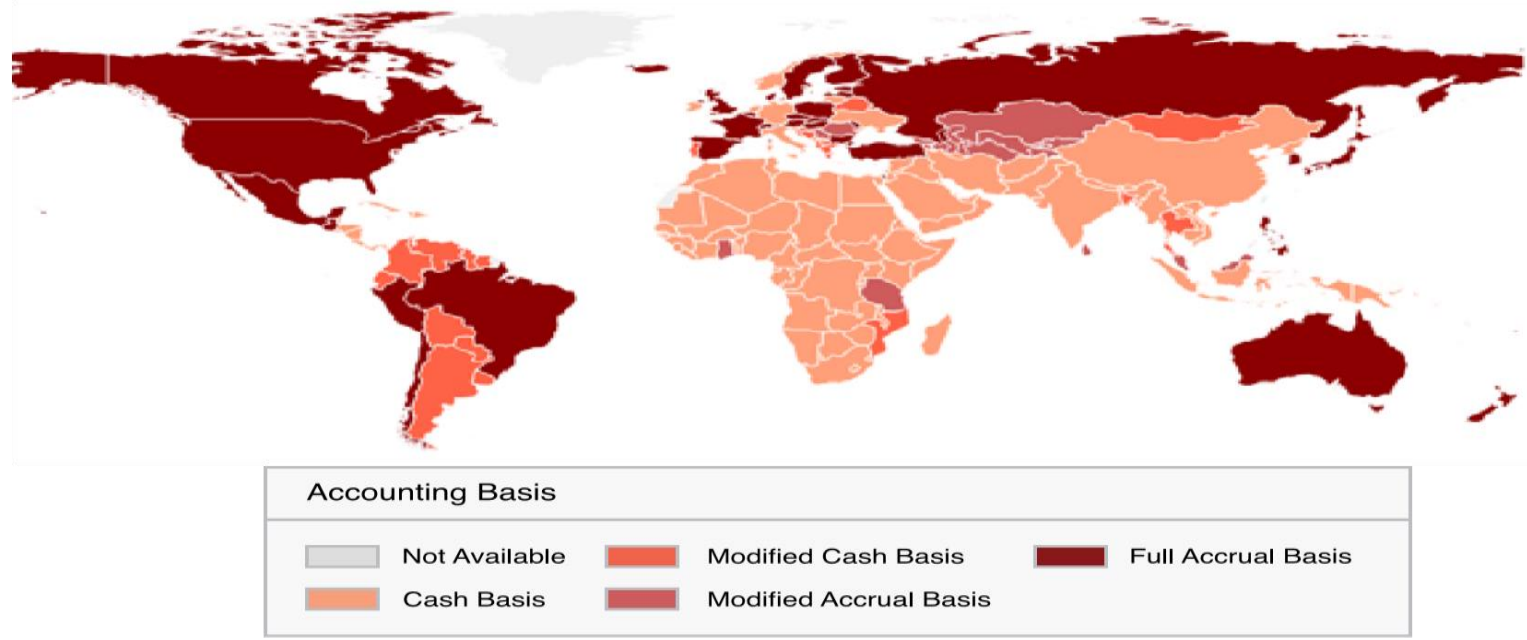

Source: OECD and IMF staff estimates, based on public information, including Blöndal and Moretti (2016) and Eurostat (2014).

Figure 1. World Accounting Basis by country

The data in Figure 1 above, which is based on public information, shows that only two governments in Africa including Ghana had adopted accrual accounting by 2016 . The rest except for one were either on cash or modified cash-based system. The data showing cash-based system for that of Cameroon in particular and CEMAC governments as a whole is misleading, giving that accrual accounting was adopted in the CEMAC Directive (2011) for all its Central African member states through the implementation of the traditional code-based accounting system with an accounting chart and budget nomenclature on accrual basis for government entities. However, that of the entire public administrative entities was adopted in 2008 while that of local government in 1998, and this was revised in 2010. 
It should be noted that there are equivalent national and international convention of accounting standards that are adopted by governments of the world over other than IPSAS (IFAC et al., 2018; PwC, 2015). The adoption of accrual for financial accounting at the Local Government level in Cameroon in 1998 was reiterated with the reinforcement of financial decentralisation in article 88 of Financial Regime of Councils (2009) modified by the General Decentralisation Code (2019). It was stated in all these financial reform laws that councils should base their accounting analysis on the recognition of all rights and obligation recorded in double entry accounting on the year in which such transactions are generated. At international level, the CEMAC Directive on the Accounting Plan of the State (2011) article 3, just like the Financial Regime of the state of Cameroon of 2007 modified in 2018 article 75, all have accrual basis of accounting enshrined as the modus operandi for the Whole of Government Accounting (WGA) on accrual basis. These pronouncement on accrual in the accounting legislation of governmental entities in Cameroon matches with the IPSAS definition of accrual accounting where all transactions are recognised once they materialise no matter the date of their cash payment or collection (IPSAS, 2014).

Even with the multiple accounting legislation instituting accrual accounting in the Whole of Government uniform accounting in the public sector of Cameroon, Mukah (2016) holds that there is still a need to study the factors determining the adoption of IPSAS accrual accounting in Cameroon. Thus, this is given that the existing public sector cash-based and fund accounting system is considered inadequate. There are therefore multiple opinions on the type of accounting basis practiced in the public sector, specifically the Local Government of Cameroon, as depicted by Mukah (2016) to be fund and cash accounting, Canavagh et al. (2016) cash accounting, and PwC (2015) modified accrual accounting.

The Cameroon Audit Bench Reports on the irregularities and poor rates in financial reporting, as well as the diversity in understanding the accounting basis practiced for financial reporting in councils are all indicative of the fact that financial accountability and performance in councils of Cameroon is still a cause for concern. What then is the level of the practice of accrual accounting in Cameroon? Has accrual accounting practices affected accountability and financial performance as envisaged by the NPM financial reforms with councils in Cameroon?

The objective of our study is therefore to;

i. Determine the degree of the practice of accrual accounting for financial accountability in councils (RO1);

ii. Assess the effect of the practice of accrual accounting on council's financial performance $(\mathrm{RO} 2)$. 


\section{Conceptual and Theoretical Literature}

IFAC et al. (2018) consider the accrual basis of accounting as a technique where the full characteristics of transactions are recognised and recorded in the economic period to which they relate. The accrual basis of accounting recognises the function of time and provides a more accurate historical record of financial transactions, as it keeps tracks and accrues values of all economic and financial transactions, regardless of whether money has transpired. The values of all assets and their accumulated depreciation, values of debts, loans and their accrued interest, salaries owed and pension liability, are computed and accounted for.

Although accrual accounting has been used in the private sector for a long time, studies have shown that it is not possible to simply adopt private sector accruals to the public sector in bulk (Christiaens et al., 2010; Wynne, 2007). Entities therefore use different entry points for accrual, as classified by Governmental Accounting Standard Board, GASB (2006), differentiating accounting systems under full accrual, modified accrual, full cash modified cash or a combination of cash and accrual bases of financial reporting and disclosures. Meanwhile to qualify for the degree of application of accrual accounting, Chan (2008) distinguishes the elastic nature of the accrual accounting concept under mild accrual, moderate accrual, and strong accrual accounting. Cash and full accrual systems of accounting represent the two end points on this spectrum of possible financial reporting basis, and a combination of numerous variations that can be put into practice. Countries that have adopted accrual accounting have therefore shown different adaptation and degrees of implementation (Pina \& Torre, 2010; Sabrina et al., 2015).

Accrual accounting is esteemed by accounting professionals as the basic foundation for a modern finance function as it plays a proactive role in providing key information for strategic and operational decisions as well as accountability (GASB, 2006; IFAC et al., 2018). PwC (2015) therefore deems it mandatory for all Governments to update and adopt sound accounting and reporting rules as part of "democratic accountability and intergenerational fairness" (p.7), in order to contribute to better service performance and sustainable public finance. Given that there is no single perspective to capture the accountability concept, Onurorsh (2012) noted that accountability can be segmented into four categories: political accountability, managerial accountability, social accountability, and financial accountability. In this context, financial accountability entails an obligation to report on the intended and actual use of resources by those to whom such resources are entrusted.

In Opanyi (2016), the adoption of cash-based IPSAS in Kenya had a positive impact on the quality of financial reporting as compared to the old accounting standard, but it had no significant effect on accountability and 
transparency. Consequently, the move to IPSAS accrual accounting, though challenging, was deemed mandatory for the provision of a better quality of financial information, enhanced decision, transparency, and accountability.

Deaconu et al. (2011) demonstrated the usefulness of accrual accounting over cash-based accounting, with the exploration of performance proxies such as fixed assets, liabilities, revenues, and operating cost through a quantitative approach based on content analysis of financial statements. It was proven that the Romanian public accounting system increasingly improved on the quality of its public management system over time.

Based on the doctrinal components of NPM that emphasizes the transposition of private style management into the public sector, many studies have raised concern on the adoption of accrual accounting as an appropriate financial reporting and management technique to enhance accountability, decision making, and efficient performance in the public sector (Wartkins et al., 2007; Wynne, 2007; Hyndman \& Connolly, 2011; Ritonga, 2018).

Wynne (2007), for instance, while not categorically against the use of accrual accounting in the public sector opines that accrual accounting should not be considered in isolation, but as part of the overall NPM reform process. The study observes that many countries have misconstrued pressure from the IMF, the World Bank, the OECD, and the IFAC to change to accrual accounting, though it is not a tried and tested approach but rather a technical change made for political reasons. Accrual accounting is considered neither as a priority nor an end in itself, but as a means of shifting the emphasis of the budgeting system away from cash inputs towards outputs and outcomes. Rather than focusing on the adoption of accrual accounting like a one-size-fit all, public sector organisations should be concerned with how accounting and financial management can best improve the management of public services.

The NPM, the institutional and agency theories are relevant in understanding the rationale for the adoption and practice of accrual accounting and the functional behaviours of financial and accounting officials in their contractual relationship to render account through the production of financial reports to local government stakeholders. By this contractual relationship based on the principal agency theory, council managers (accountant and vote holders) as agents are obliged to render account to their principals on the resources under their responsibility. This theory raises the problem of the possibility of the agents (financial and accounting officers) to manipulate the reports on financial information for their own self-interest, with the risk of lack of probity in accountability, especially when they are not adequately monitored and rewarded. Such practices are referred to as decoupling in accounting, where accounting is manipulated to make up semblance of reality, for the gallery or ceremonial purpose, in order to cover up personal gains. Such self-aggrandizement and legitimate seeking couched in cosmetic accounting 
has been preponderant in developing countries (Awasom, 2018; Adhikari et al., 2011; How \& Alawattage, 2012).

\section{Area of Study and Methodological Approach}

The study examines accounting in councils otherwise referred to as municipal or local governments in Cameroon within the context of New Public Management reforms development. The period of study is five years, 2012 to 2017 , of the statutory implementation and practice of accrual accounting in councils. Out of a total of 374 councils, 50 councils and their financial statements were sampled and clustered according to their statutory categories as city councils, sub divisional councils, and municipal councils as defined by the law on the orientation of Decentralisation in 2004.

\section{Research Design}

Using accountability and efficiency as the performance proxies, the study employs a mix of qualitative and quantitative research with a triangulate method to collect both primary and secondary data.

\section{Data Collection}

Primary data was collected through Likert scale questionnaires (see Appendix 1 \& 2), administered to accounting officers, and filled based on details of their accounting books of original entries. This helped to assess the content coverage and timeliness of the use of accrual accounts in these books of original entry and unpublished financial statements. In addition, it enabled the ranking of councils practicing accrual accounting under strong, moderate, and mild practice of accrual accounting to discharge financial accountability as in research objective one (RO1).

Secondary data was collected through content analysis on end of year selected financial statements (The budget summary statement and operating statement) to establish the council financial ratios as defined by the law on the Financial regime for councils. Earlier works on public sector performance measures, such as Bukenya (2014), used revenue collection and operating expenditure ratios on budgeted and actual values of the budget statement to determine the levels of financial performance in city divisions of the Kenyan local government. However, our study found the statutory provision of staff cost ratio, operating ratios, and investment ratios as suitable variables to measure financial performance of local governments in Cameroon. This then constituted the variables for the second research objective (RO2) of this study. Structured interviews and open-ended discussions were done to know the situation of competent human resources, outsourcing for expertise, and the use of ICT as complementary variables to back up findings on the practice of accrual accounting in councils in Cameroon. 


\section{Data Analysis}

Descriptive Statistics: This was used to measure the level (degree) of the practice of accrual accounting as in RO1. Two factors were considered to classify the practice of accrual accounting; the content coverage on the recognition of accounts for transaction analysis, and the timely recognition of accounts as well. The criteria for assessing the different degrees of the practice of accrual accounting for financial accountability were derived from Chan (2008) and Sabrina et al. (2018) classification of accrual accounting applications as follow.

Strong accrual (SA) recognises all financial and non-financial transactions promptly as they occur during the accounting period. Such transactions are identified as assets and liabilities (A \& L), revenues and expenses ( $\mathrm{R} \&$ Exp), debtors and creditors ( $\mathrm{Db} \& \mathrm{Cr})$, depreciation and provisions (Dep \& Pr).

Moderate Accrual (MOA) recognises financial transactions as timely as they occur during the accounting period such as assets and liabilities (A \& $\mathrm{L})$, revenues and expenses ( $\mathrm{R} \& \mathrm{Exp})$, and debtors and creditors ( $\mathrm{Db} \& \mathrm{Cr})$.

Mild Accrual (MiA) or Modified Cash (MC) recognises all transactions on the cash base during the accounting period and sets up unpaid assets and liabilities, revenue and expenses, debtors and creditors at the end of the accounting period. Thus, MoA is established only at end of the accounting period.

With the above classification, measures of central tendency such as mean, median, and standard deviations were done to assess the level of the practice of accrual accounting for financial accountability as in RO1. Percentage scores on the degree of practice of accrual accounting by each category of councils (city, sub divisional and municipal council) as well as their financial performance ratios were presented in contingency tables, followed by a histogram or bar chart to rank the scores.

\section{Inferential Statistics}

To test the relationship between the practice of accrual accounting and financial ratios as a proxy to financial performance as in $\mathrm{RO} 2$, a diagnostic was first done with the Pearson Product Movement Correlation (PPMC) test before proceeding to a Multiple Regression Analysis (MRA) in a panel data with all the variables in our study.

Given that PPMC, according to Chee Jennifer (2013), is the most commonly used test of association that measures the strength, direction and probability of the linear association between two intervals or variables, we found it suitable to test the normality of the variables in our study. The two independent variables being the two levels of the practice of accrual accounting (mild and moderate accrual) respectively were applied on two 
dependent variables (investment and staff cost ratios as proxies to financial performance).

Econometric Modelling to Examine the Levels of the Practice of Accrual Accounting on Efficiency as Proxy to Financial Performance in Councils

- $\quad$ Strong accrual accounting practice $(S A)=3$

- Moderate accrual accounting practice $(A A C M o)=2$

- Mild accrual accounting practice 1 (AACMi)

- No accrual accounting practice 0

Since none of the councils were found to be significantly on strong accrual basis, we consider the two cases coded as 2 for moderate and 1 for mild accrual accounting practice as separate variables to measure the degree of accrual accounting practice in councils in Cameroon.

To measure efficiency as a proxy to financial performance in councils for RO2, inspiration was drawn from Vavrek (2018) selected criterion method to evaluate efficiency which includes financial indicators such as cost minimisation analysis, cost-benefit analysis, as well as investment rating methods. While others like Bukenya (2014) consider revenue collection and expenditure performance as measures of financial performance, this study employs the staff cost, investment ratio, and operating ratios as the statutory financial ratios spelt in article 39 of the Financial Regime of 2018 for council in Cameroon, where Staff cost (employment ratio) $\leq 35 \%$ of operating budget, investment ratio $\geq 40 \%$ of total budget, and operating ratio $\leq 60 \%$ of total budget. Financial performance is considered to be efficient if it takes the following values: 3 if all the ratios are respected, 2 if only two of the ratios are respected, 1 if only one of them is fulfilled, and 0 if none of the efficiency ratios are obtained.

Model Specification for the Relationship between Financial Efficiency as Proxy to Performance and Accrual Accounting Practice

A multiple regression test was administered to assess the relationship between the practice of accrual accounting and financial performance for each category of councils.

$$
F E=f(A C A P, C d u m) \ldots \ldots \ldots \ldots \ldots \ldots \ldots \ldots . .(1)
$$

Here,

$F E$ is the single indicator for financial efficiency as performance proxy for the dependent variable.

$A C A P$ is the accrual accounting practice that makes the independent variable. Cdum represents dummy variables for councils in terms of their category, namely City councils, Sub-divisional and municipal councils respectively. 


\section{Presentation of Results}

\subsection{Results of Descriptive Statistics on the Degree of the Practice of} Accrual Accounting as a Performance Proxy to Discharge Accountability in Councils in Cameroon (RO1)

The descriptive statistical presentation is done in two folds. Firstly, it involves an assessment of percentage scores on the degree of practice of accrual by each category of councils presented in contingency tables, followed by a histogram or bar chart to rank the scores of the degree on the practice of accrual accounting.

Table 1. Percentage scores on the practice of accrual accounting by all the 3 categories of

\begin{tabular}{|c|c|c|c|c|c|c|c|c|}
\hline \multirow{2}{*}{$\begin{array}{l}\text { Category of councils } \\
\text { Levels of accrual practice }\end{array}$} & \multicolumn{2}{|c|}{$\begin{array}{l}\text { City council } \\
\text { (mega urban } \\
\text { communities ) }\end{array}$} & \multicolumn{2}{|c|}{$\begin{array}{l}\text { S.D. council } \\
\text { (semi-urban } \\
\text { communities) }\end{array}$} & \multicolumn{2}{|c|}{$\begin{array}{l}\text { Municipal } \\
\text { Council (Semi } \\
\text { urban \& rural) }\end{array}$} & \multicolumn{2}{|c|}{ Totals } \\
\hline & No. & $\%$ & No & $\%$ & No & $\%$ & No & $\%$ \\
\hline Strong Accrual & 0 & $0 \%$ & 0 & $0 \%$ & 0 & $0 \%$ & 0 & $0 \%$ \\
\hline Moderate Accrual & 2 & $5 \%$ & 2 & $5 \%$ & 5 & $12 \%$ & 9 & $23 \%$ \\
\hline Mild Accrual & 2 & $5 \%$ & 9 & $23 \%$ & 20 & $50 \%$ & 31 & $77 \%$ \\
\hline Total respondent councils & 4 & $10 \%$ & 11 & $28 \%$ & 25 & $62 \%$ & 40 & $100 \%$ \\
\hline
\end{tabular}

Source: Students survey 2018.

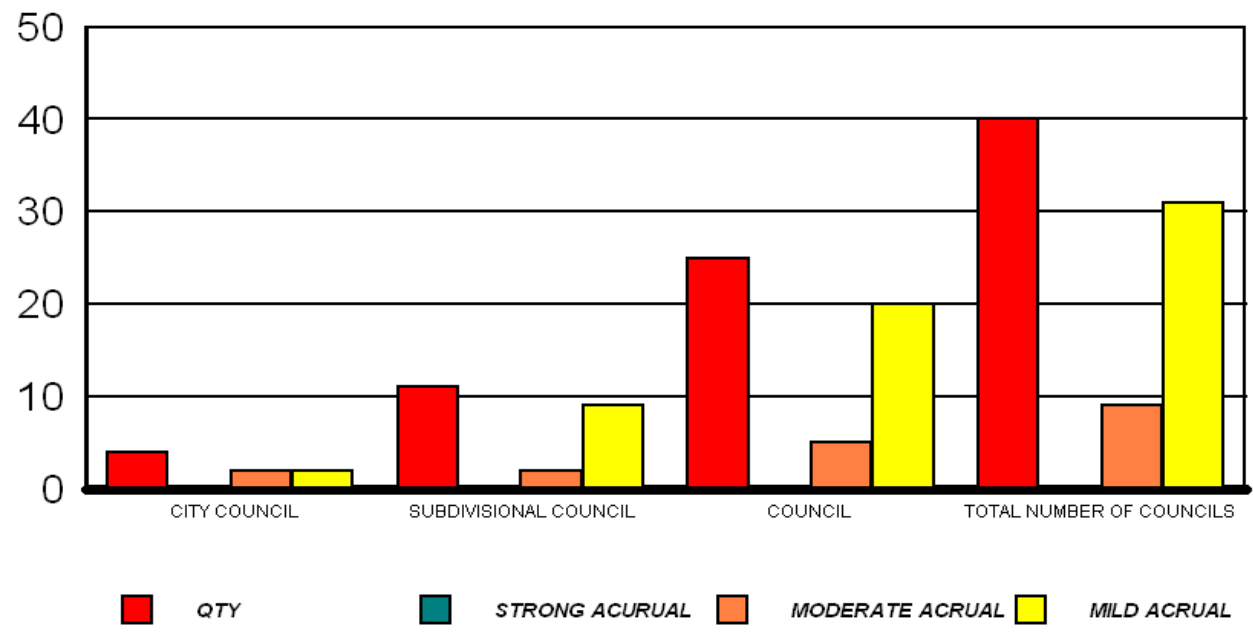

Figure 2. The degree of practice of accrual accounting by all the 3 council categories Source: Computing using Microsoft Excel

Table 1 and the histogram revealed that 40 out of 50 councils adequately responded to the questionnaires. No council practiced strong accrual (with zero) as councils could not account for the full value of their assets and liabilities. Also, they presented a comprehensive balance sheet as prescribed by the council and public sector accounting legislation in Cameroon. 
Nine councils, about $23 \%$ are under moderate accrual accounting practice, can account for some of their assets and liabilities such as debtors and creditors, salary owed, and interest on loans during the year. However, they are unable to timely account for the loss of value (depreciation) of assets, pension, and social benefits during the financial year.

With 31 councils, about $77 \%$ under mild accrual accounting practice which is close to modified cash accounting, it was observed that they work mostly on budget and cash accounting, recording the collection and disbursement of funds, and then preparing their financial statements on accrual basis at end of the accounting period. This means they cannot timely account for their debtors, creditors, depreciation, and pension expenses during the financial year. The $23 \%$ of council under moderate accrual practice are therefore more accountable than $77 \%$ under mild accrual accounting as they portray a better quality of financial information in terms of content coverage and timeliness in the recognition and reporting of financial transactions.

Table 2. Financial performance ratio for all the 3 categories of councils

\begin{tabular}{|l|l|l|l|l|}
\hline Council category & $\begin{array}{l}\text { City council ( } \\
\text { mega urban } \\
\text { communities }\end{array}$ & $\begin{array}{l}\text { S.D. council } \\
\text { (semi-urban } \\
\text { communities) }\end{array}$ & $\begin{array}{l}\text { Council } \\
\text { (semi } \\
\text { urban/ } \\
\text { rural) }\end{array}$ & $\begin{array}{l}\text { Total } \\
\text { average. }\end{array}$ \\
\hline Investment Ratio & $34.14 \%$ & $37.7 \%$ & $43.5 \%$ & $40.9 \%$ \\
\hline Operating Ratio & $65.9 \%$ & $62.33 \%$ & $56.54 \%$ & $59.1 \%$ \\
\hline Staff cost ratio & $32.2 \%$ & $44.5 \%$ & $34.5 \%$ & $36.98 \%$ \\
\hline
\end{tabular}

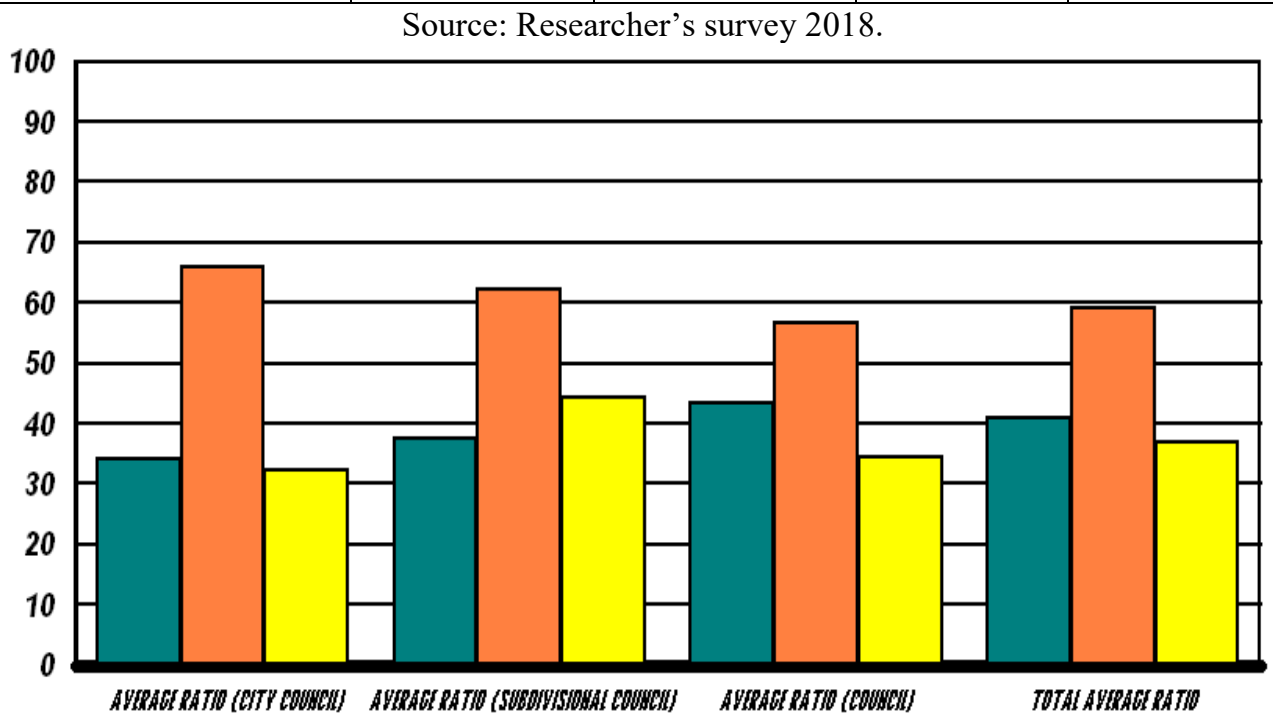

INVESTMENTRATIO $\square$ OPERATING RATIO

STAFF COVERAGE RATIO

Figure 3. Ranking financial performance ratio by all 3 categories of councils Source: Computing using Excel. 
From the table and chart above, the city councils have the highest operating ratio (65.9), the last in investment ratio (34\%), and the lowest in staff cost ratio (32.2\%). Sub-divisional councils have the highest staff cost ratio $(44.5 \%)$, the second in operating ratio $(62.2 \%)$ as well as investment ratio (59.1\%). Municipal Councils have the highest in investment ratios (43.9\%), lowest operating ratio and second in staff cost ratio (34.5\%).

The general trend therefore shows that municipal councils (predominantly in rural communities) have the best financial performance followed by sub-divisional councils (of semi-urban communities). In addition, the worst in financial performance is the city council (of mega cities and urban areas) with lowest in investment and staff cost coverage.

\subsection{Results on the Level of Accrual Accounting Practice and Financial Performance by Councils in Cameroon (RO2)}

With the understanding that accountability and efficiency are inextricable linked concepts in the measurement of performance (Harrison et al., 2012; Watkins et al., 2007; IFAC et al., 2018; PwC, 2015), this section seeks to evaluate this assertion by examining the effect of the different levels of the practice of accrual accounting on financial performance in councils in Cameroon using measures of central tendency.

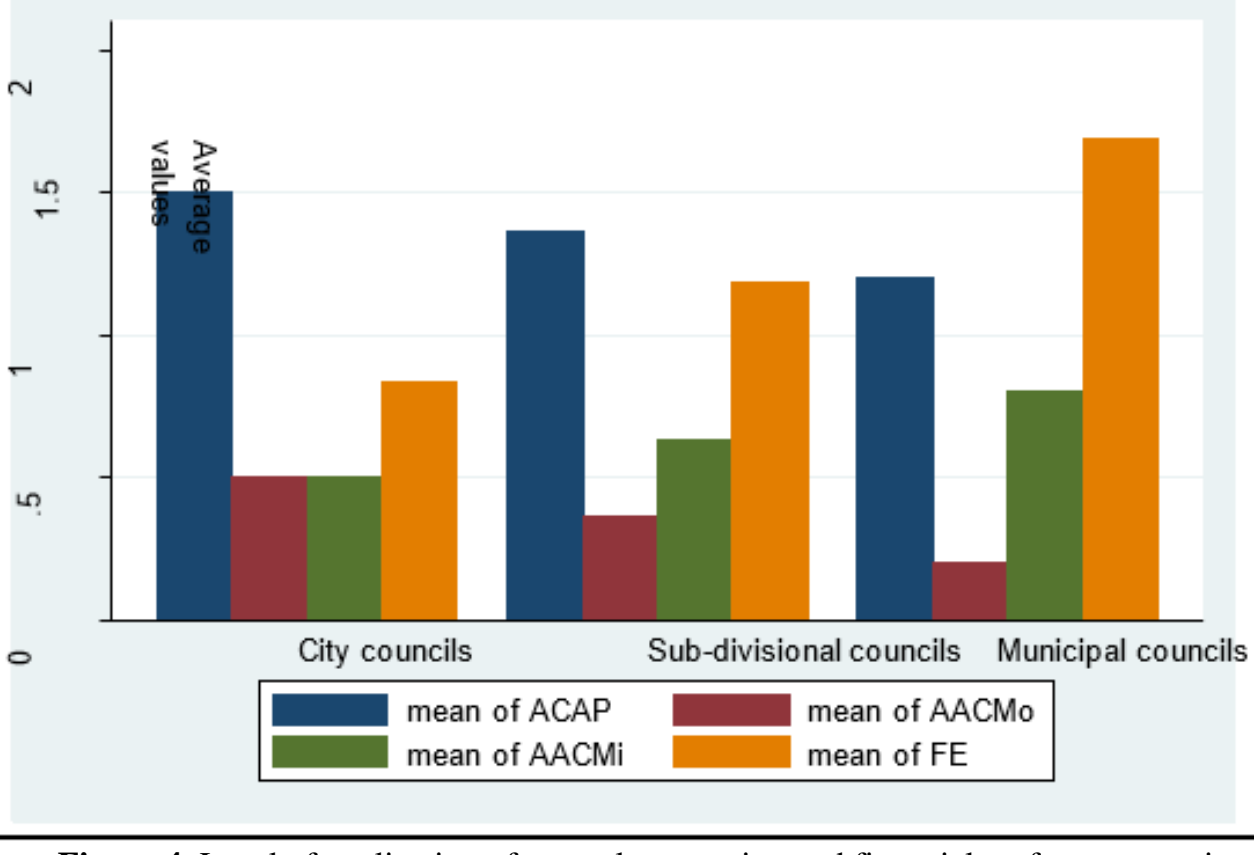

Figure 4. Level of application of accrual accounting and financial performance ratio Source: Researcher's field survey, 2018 
The histogram in Figure 4 above indicates that the distribution is evenly skewed, signifying a symmetric normal probability distribution. The mean level of the practice of accrual accounting is therefore the same as the median since the histogram is symmetric.

The mean level of the practice of accrual accounting (ACAP) by the City councils is 1.5 units, 0.5 units for moderate accrual (AACMo), mild (AACMi) 0.5 with a mean level of financial efficiency (FE) as performance proxy being 0.75 unit. Sub-divisional councils has 1.3 as mean level of the practice of accrual accounting, 0.36 for moderate (AACMo), 0.63 for mild (AACMi), and 1.3 units for financial efficiency (FE) respectively. Meanwhile, municipal councils accrual accounting practice stands at 1.2 units, moderate (AACMo) 0.2, mild (AACMi) 0.8, and financial efficiency (FE) 1.7 units respectively.

From the statistics, we notice none of the councils under study practice strong accrual accounting. Consequently, there is a higher rate of mild accrual accounting practice by sub divisional council and municipal council that also score a higher level of financial performance than the few under moderate accrual accounting predominantly of city councils. It therefore means that financial performance is at its best with mild accrual accounting practice predominantly by sub divisional councils and municipal councils at semi urban and rural areas.

\subsection{Result of Inferential Statistics on the Effect of the Practice of Accrual Accounting on Financial Performance by Councils in Cameroon (RO2)}

The results obtained from the descriptive statistics showed that only two levels of accrual accounting was predominantly practiced in councils in Cameroon, i.e., mild and moderate accrual accounting practices. These two levels were therefore retained for the test of their relationship with financial performance using PPMC and analyzed with a MRA on a panel data for the selected research variables.

\subsubsection{Results of the Pearson Product Movement Correlation Test}

A diagnostic test was preliminarily done using the Pearson Movement Correlation Test (PMCT) to assert the relationship between the variables of this study: the levels of accrual accounting practice for the independent variable, and financial ratios as proxies to financial performance for the dependent variable. The results obtained are displayed as follow; 
Table 3. Results of the Pearson Product Movement Correlation (PPMC) Test.

\begin{tabular}{|c|c|c|}
\hline \multirow{2}{*}{ Test of Relationship } & \multicolumn{2}{|c|}{ Value } \\
\cline { 2 - 3 } & $\begin{array}{c}\text { Mild Accrual } \\
\text { (Mi) }\end{array}$ & $\begin{array}{c}\text { Moderate Accrual } \\
\text { (MO) }\end{array}$ \\
\hline Pearson chi2(39) & 40.0000 & 34.0000 \\
\hline Probability value (Pr) & 0.026 & 0.426 \\
\hline Fisher's exact test & 0.000 & 0.230 \\
\hline Cramér's V & 1.000 & 0.0161 \\
\hline
\end{tabular}

Source: Researcher's field survey, 2018

Table 3 above, based on the relationship between accrual accounting and performance, shows that the Pearson chi2 at 39 degrees of freedom is 40.0000 for mild and 34.0000 for moderate accrual accounting practice. The Probability value (Pr) for Mi is 0.026 and Mo is .426; the Fisher's Exact test value is 0.000 for Mi and 0.230 Mo respectively. All these values are less that $5 \%$ level of significance. Looking at the Cramer's V, Moderate accrual accounting practice is at 0.0161 which is less than the 0.25 standard value. The general trend shows that there is a positive relationship between accrual accounting and performance in councils. In spite of this high strength of positive relationship, the correlation between the independent variable (practice of accrual accounting) and dependent variable (financial performance) remains insignificant as shown by their Pr. Value and Fisher's exact test values, which is less than 5\% level of significance. There may be need to justify this positive but insignificant relationship as stated in Glewwe (2016) and Opanyi (2016). Hence, in this case, this same result is reflected in the multiple regression analysis done for the development of research objective two (RO2), to know the effect of the practice of accrual accounting on financial performance in councils in Cameroon. 


\subsubsection{Result of the Pooled Regression Analysis}

Table 4. Pooled regression analysis on the effect of accrual accounting practice on financial performance in councils

\begin{tabular}{|c|l|l|l|}
\hline Source & SS & $\boldsymbol{d} \boldsymbol{f}$ & MS \\
\hline $\begin{array}{c}\text { Model } \\
\text { Residual }\end{array}$ & 4.69551242 & 3 & 1.56517081 \\
\hline Total & 31.63946 & 39 & 0.878873889 \\
\hline & 36.3349724 & 39 & 0.93166596 \\
& & & \\
\hline
\end{tabular}

$$
\begin{aligned}
& \text { Number of observation= } \\
& 40 \\
& F(3,36)=1.78 \\
& \text { Prob }>F=0.1682 \\
& R-S q u a r e d=0.1292 \\
& \text { Adi } R \text {-squared }=0.0567
\end{aligned}
$$

\begin{tabular}{|l|l|l|l|l|l|l|}
\hline FE & Coef & Std Err & T & \multicolumn{2}{|l|}{ P<(t) } & \multicolumn{2}{|c|}{ 95\% Conf. Interval } \\
\hline ACAP & 0.6212249 & 0.3412877 & 1.82 & 0.77 & -0.0709386 & 1.313388 \\
\hline Subd_Council_dum & 0.4866064 & 0.5493469 & 0.89 & 0.382 & -0.6275207 & 1.600734 \\
\hline Municipal_Council_dum & 0.8548675 & 0.5151275 & 1.66 & 0.166 & -0.1898596 & 1.899595 \\
\hline Cons & -0.276707 & 0.6941126 & -0.04 & 0.968 & -1.435396 & 1.3800055 \\
\hline
\end{tabular}

Source: Researcher's field survey, 2018

Table 4 looks at the relationship between accrual accounting practice (ACAP) and financial efficiency (FE) as a proxy to financial performance in 40 councils. The table shows that accrual accounting practice (ACAP) coefficient for financial efficiency is 0.6212249 . This means a unit increase in accrual accounting practice will lead an increase in council financial management performance by 0.62 units. The probability value 0.077 is greater than 0.05 or $5 \%$ level of significance. This implies that accrual accounting has a slightly insignificant effect on financial performance of the councils in the study area. Looking at the R-Squared value of 0.1292 or approximately $13 \%$, which is the coefficient of determination of the goodness of fit, shows that accrual accounting practice accounts for only $13 \%$ improvement in the financial management performance of the councils in question. The factors not included in this analysis, or the stochastic term, accounts for $87 \%$ of the councils' performance. This may be due to the absence of other complimentary factors needed to reinforce the full practice of strong accrual accounting in ways that can significantly impact their financial performance in councils in Cameroon.

However, details on content analysis of financial statements and inferences drawn from interviews with council vote holders and accounting officials show that some councils in the city and urban areas sporadically attempted the practice of strong accrual accounting to enable them participate in the city's stock market. The reinforcement of other variables such as ICT and outsourcing for expertise was often required to have full accrual accounting done by councils. It therefore means that accrual accounting alone cannot significantly impact the financial performance of councils without the integration of other known financial data as complementary variables to enhance the practice of accrual accounting. 
Glewwe (2016), for instance, advanced on a number of potential reasons for an insignificant result among which was the need to integrate other complementary variables to improve on educational outcomes in developing countries. In the context of accrual accounting practice, ECA (2003) proposes that the use of ITC, professionalism in human resources management, capacity building or outsources for accounting expertise are the exigent collaborative elements for any incremental approach in accrual accounting technology to enhance accountability and efficiency in the NPM reforms agenda.

In fact, Ouada (2004), FEE (2016), and PwC (2015) all contend that a successful implementation of accrual accounting needs a collaborative set of factors such as good communication across work units to get quick information, as well as an acceptable, convenient, and suitable ICT package as mandatory for a successful implementation of accrual accounting that can enhance reforms and performance in the public sector. This may therefore be some of the stochastic elements that needed to be explored to fill the $87 \%$ performance gaps that can yield a significant positive relationship between our research variables.

\section{Discussion of Results}

\subsection{Multiple Levels of the Practice of Accrual Accounting for Accountability}

The accounting legislation for councils in Cameroon defines accrual accounting as a modus operandi for councils without specifying the different basis or levels as entry point for accrual accounting application, which is the spectrum of existing accounting basis explored. While Mukah (2016) holds fund and cash accounting for the public sector of Cameroon, IFAC et al. (2016) cash accounting and PwC (2015) modified accounting, our study demonstrates a multiple level of accrual accounting practiced in councils since the introduction of accrual accounting in the public sector in Cameroon began with the local governments in 1998 . While about $77 \%$ predominantly of municipal councils and sub-divisional councils are operating under mild accrual (close to modified cash) basis, $23 \%$ of mostly City councils operate under moderate accrual accounting during the year and sporadically on strong accrual accounting that was not consistent during the span of our study. With the sporadic practice of strong accrual accounting by some councils due to challenges in instituting the other complementary variables such as the use of ICT, sourcing for expertise and collaboration among work units within the frames of the decentralisation machinery, no council significantly operate on full accrual accounting basis to attain the efficient performance and accountability envisaged by the NPM financial reforms of councils in Cameroon. 
Content analysis of accounting records and discussions with council officials revealed that councils had the latitude to navigate from modified cash accounting during the financial year and mild accrual accounting at year end, and sometimes on strong (full) accrual basis as the financial reporting need arises. With such multiple levels on the practice of accrual accounting in the Cameroon public sector and the Local Government in particular, public accountants risk having the latitude to navigate from one level of accrual application to the other. With this they are able to manipulate with the recognition and reporting of transactions in ways that may make financial information look better or worse according to their whims and caprices. This legislative void of not specifying the level(s) of application of accrual by councils (based on their size or resources) may lead to creative and manipulative accounting solutions by finance and accounting officials (as reporting agents) at their own convenience. For instance, they can decide not to report on the net values of assets. Also, they can delay with the values of debtors and creditors to manipulate with huge sums that could have been accrued (to their advantage) and thereafter report on it only on a later date, at the end of the year or not report at all. An example is the case of pension and capitalisation of assets couched under mild accrual accounting practice. In fact, this explains why pensioners in Cameroon queue up in desperation at municipal treasuries, with tons of old documents to justify their pension allowances which could have been duly computed on accrual basis at the time their services were rendered during each financial year.

Heterogeneous level of accrual accounting application may lead to inconsistency and ambiguities arising from the multiple levels of financial disclosure and the discharge of accountability between councils, and from one accounting period to another (i.e., over space and time). This may render accounting information inconsistent, difficult to understand, uncontrollable, and unreliable. Such failures of accrual accounting reforms to achieve enhanced accountability has been recorded to counter the ungrounded claim that accrual accounting renders accounting more accountable (Carnegie, 2005; Broadbent et al., 2008), especially with the public sector that has myriad of challenges in capturing the activities of multiple stakeholders that are financial and non-financial in nature.

\subsection{Ambiguity and Contradictions in the Discharge of Accountability with a Hybrid of Financial Performance Relationship with Accrual Accounting Practice}

From the analysis and findings on the degree of application of accrual accounting and financial performance in councils in Figure 4, city councils portray the best accrual accounting practice at 1.5 units at moderate accrual accounting practice though having the lowest in financial performance of 0.5 
units. Meanwhile, at mild accrual practice, it scores 01 unit with a mean level of performance that slightly improves to 01 unit. While city councils at moderate accrual accounting score the lowest financial performance, they have a better financial performance at mild accrual accounting that is assumed to have less accountability coverage and quality of financial reporting (Ritonga, 2018) than at moderate accrual accounting.

It is generally claimed that the move towards a higher quality of accrual financial reporting by governments demonstrates the desire to achieve greater accountability that will guarantee better public service performance and efficient public financial management (Paulson, 2006; Van der Hoek, 2005; Bukenya, 2014; PwC, 2015). Premised on this claim, it becomes ambiguous that city councils having a better quality of financial information in terms of timeliness and higher coverage in financial reporting, at moderate accrual with 1.5 units, paradoxically display the worst in financial performance with 75 units compared to the two categories of councils.

The summary of the results in Table 3 also show that about $77 \%$ of councils practicing mild accrual accounting can guarantee financial efficiency than 23\% of councils under moderate accrual accounting. Our findings therefore contradict the claim that the higher (stronger) the level of accrual, the better the quality of financial reporting and accountability, as more information can be reported in a more timely manner for an enhanced performance in the public sector (Chan, 2008; Bukenya, 2014; Sabrina et al., 2015; Ritonga, 2018). There is therefore no corroboration between the higher quality of accrual accounting, improved accountability, and efficient financial performance as in the case of the $23 \%$ of councils predominantly of city councils that show a poor financial performance at moderate accrual accounting practice. Hence, it is assumed to have a better quality of accounting due to its timely and broader coverage in financial reporting and accountability.

It is also ambiguous that management performance is at its best at mild accrual accounting where the quality of financial disclosure is low (Ritonga, 2018). This is so assumed given that mild accrual accounting does not have a broad coverage of financial information; it is claimed to be limited in the timely disclosure of financial information for prompt decision making to enhance performance and accountability in councils.

The pooled regression result of the relationship between the practice of accrual accounting and financial performance shows a positive but insignificant relationship. The positive financial performance of $77 \%$ of councils practicing mild accrual accounting should be encouraged along with the reinforcement of other reform measures such as the use of ICT, outsourcing for expertise in accounting, and enhancing human resource management and communication across the work units. Councils should not 
therefore move to moderate accrual accounting that scores a lower performance except they have the necessary human material and financial resources to complement such full accounting practice on accrual basis.

\section{Conclusion}

It has been demonstrated in our study that there are multiple levels of accrual accounting practice by councils officials in Cameroon in their endeavour to meet up with the one-size fits all accrual accounting prescriptions by the council accounting legislation in Cameroon. Councils practicing mild accrual accounting (close to cash accounting) have a relatively better performance result. Unlike in Bukenya (2014) where city division with a higher quality of accounting marked a better financial performance, City councils in Cameroon, having a sound operating budget with a better quality of financial reporting, had a poor financial performance. Therefore, it would be necessary for local government policy makers in Cameroon to sequence the level of implementation of accrual accounting based on the resources and size of the council. This will enable councils to begin with mild accrual that seem to yield better performance results, then move to moderate accrual after having gained some expertise with time. The preoccupation about performance in the public sector in terms of accountability and efficiency remains a dream yet to come true despite the implementation experience of about twenty years in councils in Cameroon. The underpinning result of this research confirms the assertion that performance measurement in the public sector is characterized by ambiguities, contradictions, uncertainties and never fixed (Lee, 2008; Model, 2009; Harrison, 2012). The assessment of performance gets more and more complex with financial accounting theory that necessitates the application of both financial and non-financial parameters, especially within the context of New Public Management Financial (NPMF) reforms (Boukaert, 2004; Elio Borgonovio, 2018). The use and integration of other non-financial parameters such as ICT, professionalism and collaboration within work units, and outsourcing for expertise in the application of accrual accounting may significantly yield a better performance result.

\section{References:}

1. Akouafane, J.C.E.O. (2009). La décentralisation administrative au Cameroun. Editions L'Harmattan.

2. Adhikari, P. and Mellemvik, F. (2011). The rise and fall of accruals: a case of Nepalese central government. Journal of Accounting in Emerging Economies. 1(2), 123-145.

3. Awasom, S.A. (2018). Institutionalising Acrual Budgetting and Accounting ; Une expérience á la Camerounaise . Tékhne - Review of Applied Management Studies. Tékhne, Special Issue, 2018, 15-27 
4. Banlilon, T., Abangma J. and Ambe, B. (2012). The dilemmas of implementing decentralization policies in a centralized state construct: evidences from some municipalities in the northwest region of Cameroon. African Journal of Social Sciences, Vol.3, No 2.

5. Bekolo, E.E. (2020). Implementation of Decentralization and Local government reforms in Turkey and Cameroon: A comparative assessment. Ph.D Thesis. Department of Political Science and Public Administration, Hacettepe University Graduate School of Social Sciences. Turkey.

6. Brinkerhoff, D.W. and Brinkerhoff, J.M. (2015). Public sector management reform in developing countries: Perspectives beyond NPM orthodoxy. Public Administration and Development, 35(4), 222237.

7. Broadbent, J. and Laughlin, R. (2003). Control and legitimation in government accountability processes: the private finance initiative in the UK. Critical perspectives on accounting, 14(1-2), 23-48.

8. Bouckaert, G. (2012). Public sector performance: Managing governments by the numbers. .In Tria, G., \& Valotti, G. (Eds.). Reforming the public sector: How to achieve better transparency, service, and leadership. Brookings Institution Press.

9. Bukenya, M. (2014). Quality of Accounting Information and Financial Performance of Uganda's Public Sector. American Journal of Research Communication www.usa-journals.com

10. Carnegie, G.D. and West, B.P. (2005). Making accounting accountable in the public sector. Critical perspectives on Accounting, 16(7), 905928.

11. Cavanagh, J., Flynn, S. and Moretti, D. (2016). Implementing Accrual Accounting in the Public Sector. Fisacal Affairs Department IMF

12. CEMAC Directive $n^{\circ}$ 03/11-UEA-195-CM-22, Relative au Plan Comptable de L'Etat. Du Caméroon. 19 Décembre 2011.

13. Chan, J.L. (2008). International public sector accounting standards: Conceptual and Institutional Issues. Google Scholar.

14. Chee, J. (2013). Pearson's Product Moment Correlation: Sample Analysis. Research Gate https://www.researchgate.net/publication/262011045

15. Cheka, C. (2007). The State of the Process of Decentralization in Cameroon. Africa Development, Vol. XXXII, No. 2, 2007, pp. 181-196

16. Chia, C.N., Kaze, T., Narcisse, S. and Njoh, N.K. (2018). Decentralization and Decentralized Cooperation in Cameroon: The Futile and Conflicting Initiatives of implementation American Journal of Humanities and Social Sciences Research (AJHSSR). e-ISSN: 2378$703 X$. 
17. Christiaens, J., Reyniers, B. and Rolle, C. (2010). Impact of IPSAS on reforming governmental financial information systems: a comparative study. International Institute of Administrative Science . https://doi.org/10.1177/0020852310372449

18. Deaconu, A., Cristina, S.N. and Crina, F. (2011). The impact of accrual accounting on public sector management: An exploratory study for Romania. Transilvanian Review of Administrative Sciences, (32E). 7497.

19. Deloitte (2020). IPSAS in your pocket.

20. Elio, B., Eugenio, A. and Bianchi, C. (eds) (2018). Outcome based performance management in the public sector. Springer International Publishing. AG 2018. ISSN 2367-0957 ISBN 978-3-319-57018-1 (eBook).

21. Federation D'Experts Comptable (2007). Accrual accounting in the public sector. Public Sector Committee . Accountancy Europe. https://www.accountancyeurope.eu/wpcontent/uploads/Accrual_Acco unting_in_the_Public_Sector_070130120072491.pdf

22. Forje, J.W. (2006). Rethinking Decentralization and Devolution of Power within the African Context: C4th - 8th December Challenges And Opportunities. In 28th Aapam Annual Roundtable Conference, Arusha, Tanzania.

23. Governmental Accounting Standards Board (2006). Why governmental accounting and financial reporting is - and should be different. White paper. USA.

24. Glewwe, P. and Karthik, M. (2016). Improving Education Outcomes in Developing Countries . Handbook of the Economics of Education 5:653-743 DOI: $\quad$ 10.1016/B978-0-444-63459-7.00010-5 retrieved October 2020.

25. Harrison, A., Rouse, P. and Villiers, C.J. (2012). Accountability and Performance Measurement: A Stakeholder Perspective. The Business and Economics Research Journal Volume 5, Issue 2, 243-258.

26. Hood, C. (1991). A public management for all seasons?. Public administration, 69(1), 3-19.

27. Hope, K.R.Sr. (2005). The New Public Management: A Perspective from Africa. In New Public Management: Current Trends and Future Prospects, K McLaughlin, S. P. Osborne and E. Ferlie eds. London: Routledge

28. How, S. and Alawattage, C. (2012). Accounting decoupled: A case study of accounting regime change in Malaysian Company. Critical Perspectives on Accounting, 403-419. 
29. Hyndman, N. and Connolly, C. (2011). Accruals accounting in the public sector: A road not always taken. Management Accounting Research 22 (2011) 36-45.

30. IFAC and CIPFA (2018). International public sector financial accountability index. Status report.

31. IPSASB (2014). The conceptual framework for general purpose financial reporting by public sector entities. Handbook of international public sector accounting pronouncements, 2017: Vol. 1.

32. Kilelo Hellen (2015). Public Sector Reforms in Africa: Focus, Challenges and Lessons Learnt. International Journal of Humanities and Social Science Invention ISSN (Online): 2319 - 7722, ISSN 2319 - 7714 Volume 4 Issue

33. Kofele-Kale, N. (2011). Local governance under Cameroon's decentralisation regime: is it all sound and fury signifying nothing?, Commonwealth Law Bulletin, 37:3, 513-530,

34. Law no 2009/011 of 10th July 2009, on the financial regime of Regional \& Local Authorities in Cameroon.

35. Lee, J. (2008). Preparing performance information in the public sector: An Australian perspective. Financial Accountability \& Management, 24(2), 117-149.

36. Mbarga, A., Etoundi, D.J. and Lachunou, A. (2003). Comptabilité Communale au Cameroun. Guide pratique de L'ordonnateur et $d u$ receveur municipale. Imprimerie Nationale. Yaoundé, Cameroon.

37. Modell, S. (2009). Institutional research on performance measurement and management in the public sector accounting literature: a review and assessment. Financial Accountability \& Management, 25(3), 277303.

38. Meyer, J. and Rowan, B. (1977). Institutionalized organizations: Formal structure as myth and ceremony. American Journal of sociology, 83(2), 340-363.

39. Muka, S.T. (2016). Factors Influencing the Acceptance of International Public Sector Accounting Standards in Cameroon. Accounting and Finance Research. Vol.5. No 2;2016.

40. Nsangou, G. and Awasom, S. (2015). Challenges of Good Governance in Africa through the Prism of a Uniform Accrual accounting Standard: Implementing Issues with Cameroon as a case Study. CODESRIA $15^{\text {th }}$ G.A, on Creating African Futures in an Era of Global Transformations: Challenges and Prospects. Sub-theme "Toward more democratic futures: making governance work for all Africans"

41. Onuorah, A.C. (2012). Accountability and public sector financial management in Nigeria Arabian Journal of Business and Management Review (OMAN Chapter) Vol. 1, No.6; January 2012 
42. Opanyi Robert, O. (2016). The Effect of Adoption of International Public Sector Accounting Standards on Quality of Financial Reports in Public Sector in Kenya. European Scientific Journal October 2016 edition vol.12, No.28 ISSN: 1857 - 7881 doi: 10.19044/esj.2016.v12n28p161

43. Ouda, H. (2004). Basic requirements model for successful implementation of accrual accounting in the public sector. Public Fund Digest, 4(1), 78-99

44. Pina, V. and Torres, L. (2003). Reshaping public sector accounting: An international comparative view. Canadian Journal of Administrative Sciences/Revue Canadienne des Sciences de l'Administration, 20(4), 334-350.

45. $\mathrm{PwC}$ (2015). Towards a new era in government accounting and reporting. PwC Global survey on accounting and reporting by central governments 2nd edition

46. Ritonga, I.T. (2018). Analysing the Quality of Accrual Accounting Implementation in Indonesia Local Governments. Jurnal Akuntansi/Volume 22(2). 162-172.

47. Sabrina, B., Loredana, C. and Guillaume, V. (2015). Analysis of Public Sector Accounting Systems in the European Union. Research in World Economy. Vol.6.No.3;2015

48. Shamsul, M.H. (2007). New Public Management: Origins, Dimension and Critical Implication. Public administration and public policy Vol. I.

49. Tani, B.V., Abangma, J.A. and Bruno, A.M. (2012). The dilemmas of implementing decentralization policies in a centralized state construct: evidences from some municipalities in the northwest region of Cameroon. African Journal of Social Sciences, 3(2).

50. Tsowa, R.T. (2017). Socio-histoire de la réforme administrative au Cameroun: de la proto-bureaucratie au Nouveau Management Public.

51. Vavrek, R. (2018). Efficiency and inefficiency of public administration. Journal of Economic Development, Environment and People, 7(1), 6-14.

52. Van der Hoek, M.P. (2005). From Cash to Accrual Budgeting and Accounting in the Public Sector: The Dutch Experience. Public Budgeting \& Finance / Spring 2005 . http://mpra.ub.unimuenchen.de/6410/

53. Watkins, A.L.C. and Edward, A. (2007). Accounting, New Public Management and American Politics: Theoretical Insights into the National Performance Review. Critical Perspectives on Accounting pp 33-58. 
54. Wynne, A. (2007). Is the Move to Accrual Based Accounting A real Priority for Public sector Accounting? International Journal of Governmental Financial Management, pp.25-38.

55. Wynne, A. and Mear Fred (2016). Government Financial Reporting Good Practices from sub-Saharan Africa. International Journal on Governmental Financial Management - Vol. XVI, No 1, 2016. 
Appendix 1. Likert scale questionnaire on the timely recognition of accrual accounting transactions. / Saisie à temps les opérations de la

\begin{tabular}{|c|c|c|c|c|c|c|}
\hline \multicolumn{2}{|c|}{$\begin{array}{l}\text { When do you record the following } \\
\text { transactions in your councils? } \\
\text { Quand est-ce que vous constatez et } \\
\text { enregistrez les opérations suivants }\end{array}$} & \multirow{2}{*}{$\begin{array}{l}1 \\
\text { Every time it } \\
\text { occurs /Chaque } \\
\text { fois dès la } \\
\text { réalisation de } \\
\text { l'opération } \\
\end{array}$} & \multirow{2}{*}{ 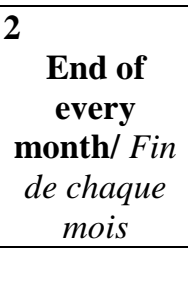 } & \multirow{2}{*}{$\begin{array}{l}\mathbf{3} \\
\text { End of every } \\
\text { quarter } \\
\text { Fin de chaque } \\
\text { trimestre }\end{array}$} & \multirow{2}{*}{$\begin{array}{l}\mathbf{4} \\
\text { End of every } \\
\text { semester } \\
\text { Fin de chaque } \\
\quad \text { semestre }\end{array}$} & \multirow[t]{2}{*}{$\begin{array}{l}\mathbf{5} \\
\text { End of Year } \\
\text { Fin de l'année } \\
\quad \text { fiscale }\end{array}$} \\
\hline 1 & 150. Loans ( Emprunt LMT) & & & & & \\
\hline 2 & $\begin{array}{l}\text { 220. Real Estate. } \\
\text { (Construction) }\end{array}$ & & & & & \\
\hline 3 & $\begin{array}{l}\text { 30 Stock/Inventory account/ } \\
\text { Compte de staock }\end{array}$ & & & & & \\
\hline 4 & $\begin{array}{l}\text { 38. Recorded claim / Droit } \\
\text { constatés }\end{array}$ & & & & & \\
\hline 5 & $\begin{array}{c}\text { 40. Debtors / } \\
\text { débiteurs ordinaires }\end{array}$ & & & & & \\
\hline 6 & $\begin{array}{c}\text { 41. Creditors / } \\
\text { créditeurs ordinaires }\end{array}$ & & & & & \\
\hline 7 & 42. Salary / salaires & & & & & \\
\hline 8 & 62. Pension / Pension & & & & & \\
\hline 9 & $\begin{array}{l}\text { 74. Interest \& Dividends } \\
\text { received /Intérêt reçus }\end{array}$ & & & & & \\
\hline 10 & $\begin{array}{l}\text { 64. Interest paid /Intérêts } \\
\text { payés }\end{array}$ & & & & & \\
\hline 11 & $\begin{array}{l}\text { 68. Depreciation expenses } \\
\text { /Amortissement }\end{array}$ & & & & & \\
\hline
\end{tabular}


Appendix 2. Timely disclosure of information on accrual accounting documents \& financial statements. Périodicité de la presentation des

\begin{tabular}{|c|c|c|c|c|c|c|}
\hline \multicolumn{7}{|c|}{ comptes } \\
\hline & $\begin{array}{l}\text { When do your prepare the following accounting } \\
\text { documents and financial statements in your } \\
\text { councils? Quand est-ce que vous préparez les livres } \\
\text { comptables et état de synthèse suivants. }\end{array}$ & $\begin{array}{l}\text { Every time } \\
\text { transaction } \\
\text { occurs } \\
\text { Chaque fois } \\
\text { réalisation } \\
\text { d'opération. }\end{array}$ & 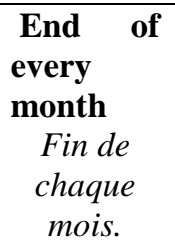 & \begin{tabular}{l}
\multicolumn{1}{c}{$\begin{array}{c}\text { End of } \\
\text { every }\end{array}$} \\
quarter \\
Fin de \\
chaque \\
trimestre
\end{tabular} & 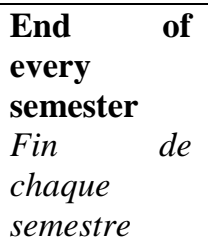 & $\begin{array}{l}\text { End of } \\
\text { Year } \\
\text { Fin de } \\
\text { l'année } \\
\text { fiscale }\end{array}$ \\
\hline 1 & $\begin{array}{l}\text { The account entry forms./ Fiche d'imputation } \\
\text { comptable }\end{array}$ & & & & & \\
\hline 2 & The Journals/le journal & & & & & \\
\hline 3 & The ledger accounts./ Le grand livre & & & & & \\
\hline 4 & $\begin{array}{c}\text { The Trial Balance / La Balance Générale des } \\
\text { Comptes }\end{array}$ & & & & & \\
\hline 5 & The Balance Sheet / Le Bilan & & & & & \\
\hline 6 & The Statement of operating result / (TSCG) & & & & & \\
\hline 7 & Situation of outstanding revenue /Restes à recouvrer & & & & & \\
\hline 8 & Situation of outstanding payment / Restes à payer & & & & & \\
\hline 9 & $\begin{array}{l}\text { Statement of Budget revenue execution / Etat des } \\
\text { Recettes Budgétaires }\end{array}$ & & & & & \\
\hline 10 & $\begin{array}{l}\text { Statement of Budget expense execution / Etat des } \\
\text { Dépenses Budgétaires }\end{array}$ & & & & & \\
\hline
\end{tabular}

